Al-Amwal: Jurnal Ekonomi dan Perbankan Syariah
ISSN: 2303-1573 e-ISSN: 2527-3876
Homepage: https://www.syekhnurjati.ac.id/jurnal/index.php/amwal
email: jurnalalamwal@syekhnurjati.ac.id

\title{
The Contribution of the Western World to the Islamic Economy in Indonesia
}

\author{
Hisam Ahyani \\ Miftahul Huda Al Ahzar Islamic College (STAIMA) Banjar City, West Java, Indonesia \\ email: hisamahyani@gmail.com \\ Memet Slamet \\ Miftahul Huda Al Ahzar Islamic College (STAIMA) Banjar City, West Java, Indonesia \\ email: memetslamet534@gmail.com \\ Naeli Mutmainah \\ Miftahul Huda Al Ahzar Islamic College (STAIMA) Banjar City, West Java, Indonesia \\ email:naelimutmainah77@gmail.com
}

\begin{abstract}
Islamic economics that is applied in various countries, including Islamic banking or in Indonesia is called Sharia Banking. This study wants to reveal how the western world's response to Islamic economics is?; and what is the contribution of the western world to the Islamic economy in Indonesia?. This type of research is a normative juridical research with the nature of this research is a descriptive legal study. This study is intended to explore the response of the western world to the Islamic economy that exists in Indonesia. This study produced findings, namely: First, the western world's response to the Islamic economy, namely the Western economic system is intended to embrace the Islamic economic system and support the existence of the Islamic economic system itself, as a result, the western world applies a free business system based on capitalism which prioritizes capital for development. economy in the Islamic world. Second, the contribution of the western world to the economy in Indonesia is a necessity which incidentally is not an Islamic State. However, in its scope, Islamic law in Indonesia in this case the sharia economy is subject to the national economic system, although in Indonesia itself the sharia economic system and conventional economics in Indonesia have their own legal umbrella. So that the Islamic economic system in Indonesia until now is an alternative concept for a prosperous economic system in Indonesia, one of which is a capitalist economic system. Islamic law, especially the Qur'an and al-Hadith. The implication of the western response to the existence of a sharia economy in Indonesia is a golden opportunity for Indonesia to develop a sharia economy, one of
\end{abstract}


which is the halal industry, halal tourism (religion), sharia economic brand, money waqf, the potential of the halal industry sector in Indonesia can be developed through halal food ( halal food), halal fashion, halal cosmetics, and so on, this means that economic freedom in Indonesia needs to be developed. In addition, halal tourism can also be developed in Indonesia, with various potentials that exist in Indonesia. Another implication related to the western response to the Islamic economy in Indonesia is the presence of a diversity of halal food. However, the development of this potential needs to make the resulting production must be based on the principles of benefit and justice, where this benefit is carried out by prioritizing sharia economics as a real need where justice is very meaningful in the economy, especially in Indonesia.

Keywords: Western World, Islamic Economics, Indonesia

\begin{abstract}
Abstrak
Ekonomi Islam yang diterapkan di berbagai negara ini diantarnya perbankan Islam atau di Indonesia di sebut dengan Perbankan Syariah. Penelitian ini ingin mengungkap terkait bagaimana respon dunia barat terhadap ekonomi syariah?; dan apa sumbangsih dari Dunia barat terhadap perekonomian islam di Indonesia?. Jenis penelitian ini merupakan penelitian yuridis normative dengan Sifat penelitian ini merupakan penelitian hukum deskriptif atau descriptive legal study. Penelitian ini dimaksudkan guna mengeksplorasi respon dunia barat terhadap ekonomi syariah yang eksis di Indonesia. Penelitian ini, menghasilkan temuan yaitu Pertama, respon dunia barat terhadap ekonomi islam yaitu sistem ekonomi Barat ini dimaksudkan merangkul system ekonomi islam dan mendukung dengan eksisnya system ekonomi islam itu sendiri, alhasil Dunia barat menerapka sistem usaha bebas yang dilandaskan pada kapitalisme yang mengedepankan modal untuk pembangunan ekonomi didalam dunia islam. Kedua, Sumbangsih dari Dunia barat terhadap perekonomian di Indonesia merupakan sebuah keniscayaan yang notabene Negara Indonesia bukan Negara Islam. Namun pada lingkupnya Hukum islam di Indonesia dalam hal ini ekonomi syari'ah tunduk pada sistem ekonomi nasional, walaupun di Indonesia sendiri sistem ekonomi syariah dan ekonomi konvensional di Indonesia memiliki payung hukum tersendiri. Sehingga sistem ekonomi Islam di Indonesia sampai detik ini merupakan konsep alternatif bagi sistem ekonomi di Indonesia yang sejahtera yaitu salah satunya adalah sistem ekonomi kapitalis hal ini diharapkan dapat membawa hal-hal positif dari keduanya dengan batasan tidak bertentangan dengan syariah Islam yang berasal dari sumber-sumber hukum Islam, khususnya al-Quran dan al-Hadis. Implikasi dari respon barat terhadap eksistensi ekonomi syariah di Indonesia adalah sebuah kesempatan emas bagi Indonesia untuk mengembangkan ekonomi syariah salah satunya Industri halal, Wisata Halal (Religi), Brand Ekonomi Syariah, Wakaf uang, Potensi Sektor Industri Halal di Indonesia dapat dikembangkan melalui halal food (makanan halal), Fashion halal, kosmetika halal, dan lain sebagainya hal ini artinya kebebasan berekonomi di Indonesia perlu dikembangkan. Selain itu wisata halal juga dapat di kembangkan di Indonesia, dengan berbagai potensi yang ada di Indonesia. Implikasi lainnya terkait respon barat terhadap ekonomi syariah di Indoensia yakni hadirnya keanekaragaman makanan halal. Namun perkembangan potensi tersebut perlu menjadikan produksi yang dihasilkan harus berdasarkan pada prinsip kemaslahatan dan juga keadilan, dimana Kemaslahatan
\end{abstract}


ini dilakukan dengan mengedepankan ekonomi syariah sebagai sebuah kebutuhan yang nyata dimana keadilan sangat berarti dalam perekonomian khususnya di Indonesia.

Kata kunci: Dunia Barat, Ekonomi Islam, Indonesia

\section{INTRODUCTION}

The development of the Islamic economic phenomenon in Indonesia in the era of the industrial revolution 4.0 as it is today has positive projections. Adiwarman Karim, an observer of sharia economics, was undermined in a more Muslim-friendly economic situation. The geopolitics that occur have an impact on the sustainability of the sharia economy, especially for Indonesia. February 2021 The geopolitics that happened was Joe Biden, the President of America who was officially inaugurated, making power in the Indo-Pacific able to rise again. but Indonesia itself looks more calm and peaceful where Indonesia is still promoting Islamic friendliness rather than interfering with the geopolitical affairs of China and America. China's strategy in taking control of the Indo Pacific is to embrace Indonesia through trade cooperation, besides that China claims that China is the second largest Muslim population after Indonesia (Karim, 2020). Therefore, Indonesia needs a strategy in this regard, namely by developing massively in the field of Islamic economics. Especially during the current COVID-19 pandemic, which is not over yet.

The need for a study in the philosophy of Islamic banking in Indonesia if we review it comes from or is a branch of the Philosophy of Islamic Law which is a philosophical concept from Muamalah where the concept of banking activities uses a profit-sharing system based on Islamic law and does not contain usury as previously found in at Conventional Banks. Darmalaksana found that life in this world is actually controlled by two great forces, namely the economy and faith or religion. Economic life is the standard of living of a country and nation. The advantage of a country is measured by the level of its economic progress and the measure of the degree of success is very materialistic. However, a new phenomenon has arisen, namely that economic power is no longer focused on material strength, but also seeks ways to integrate economics with ethical and spiritual forces, known as integrative business ethics and spirituality. Economists such as M. Umer Chapra, Muhammad Abdul Mannan, An-Naqvi, M. Nejatullah Shiddiqy, Kursyid Ahmad, agree that only an economic system based on ethics and morals is worthy of managing the global economic system. Likewise, experts in Islamic legal philosophy state that the concept of integrative economic ethics is only compatible with the presence of Islamic economics. Therefore, this results in significant understanding in understanding the nature of economics in the study of Islamic legal philosophy (Darmalaksana, 2015).

Studies and discussions about what Islamic economics is in Indonesia have developed and become a more heated discourse to be studied. At the same time, economic instruments that are very urgent with Islam have also begun to appear in almost all world economic systems. Along with the existence of the financial institutions mentioned above, Islamic banks have become a special attraction for the economic community to be enjoyed and utilized in the process of financial regulation and Islamic business activities. Banks as intermediary institutions, are designed in such a way as to process interest in order to stimulate investment, savings and financing or credit. Furthermore, Abdul Mannan argues that there is a distinct uniqueness of Islamic 
law, which is related to the breadth and depth of its principles regarding all human problems that apply throughout time. All the foundations and sources of Islamic law are permanent and eternal miracles, this miracle means that Islamic law can not only be compared with ebb and flow laws, but also with simple and exact western-style laws. Even so, Islamic law always produces new truths and inclusive guidance at every time and level, guidance is also compared for mankind through a series of fundamental and eternal revelations that have been commanded by Allah SWT. At this level, it is necessary to explore the basics and sources of Islamic Law as a whole, in order to determine that it is all with constant guidance for mankind in every age to come. We all know that in principle there are four sources of Islamic law including the Qur'an, alSunnah and al-Hadith, Ijma, Qiyas and Ijtihad ulama (Mannan, 1993 : 28).

The perspective of sharia/Islamic economics is used as an unlimited attraction, humans are given the freedom to develop the potential that exists in sharia economics, especially in Indonesia. Allah swt created this universe, given completely to humans, it will never run out, this is because what is contained in this universe contains a lot of potential wealth that has not been fully explored by humans. Therefore, humans are required to explore the natural wealth contained in it which has no limits, so that an attitude arises that has the power of creativity in finding new things that are realized to meet the needs of every human being. Everything that was created by Allah SWT on this earth and the universe is used and utilized for humans, so that all of Allah's creations are not wasted for humans (Ridwan, 2010: 18).

The development of Islamic economics in the world can be found starting from the emergence of Islamic banks in various countries. The Islamic economy began with the presence of Islamic banking as a financial institution based on ethics based on the Qur'an and al-Hadith. The main milestone in the establishment of Islamic banking was the operation of Mit Ghamr Local Saving Bank 1963 in Cairo, Egypt (Musyafah, 2019). With the doctrine of the Islamic Economy, which is an economic system with a legal basis used, namely Islamic law, now the Islamic Economy, although it uses the basis of Islamic law, does not prevent people who are non-Muslim or non-Muslim from taking part in the Islamic economic system. Basically, Islamic economics has the aim of prospering, not just looking for profit, so that many countries that do not have a majority Muslim community or even liberal countries participate in implementing Islamic economics on various sides. Islamic economics that is applied in various countries, including Islamic banking or in Indonesia is called Sharia Banking.

Maqaid Syariah as the basic foundation of Islamic economics in the Industrial Revolution 4.0 era for Muslims in Indonesia in recent years, many Islamic countries have proposed an Islamic economic system that reaffirms that traditional Islamic values are revived. The state wants a complete system that includes specific patterns and areas of social and economic behavior that does not involve reformulation of Islamic ideology or compromise of its teachings. In this economic practice, it is made to comply with the commands contained in the Qur'an, without reinterpreting the basic doctrine. The process of Islamization of the economic system involves economic institutions with a certain Islamic identity. The process seems to be gaining momentum over time. New institutions have been established, such as Islamic banks and development aid agencies, with the aim of translating sharia economic ideals into practical business solutions. Islamic economics is closely related to and is part of the concept of Islamic life. In recent developments such as cash waqf (Ahyani and Muharir, 2021), digitalization of 
the sharia economy (Ansori, 2016), these two models are a form of development that is actually carried out by people in Indonesia.

The uniqueness of this research is the response or western perception of Islam, especially in the field of sharia economics, especially in Indonesia, it needs to be studied because the doctrine of sharia economics in Indonesia in the era of the industrial revolution 4.0 is very much needed to develop the potential that exists in sharia economy. Where Indonesia has enormous potential in the international arena. For this reason, researchers will examine how the response and contribution of the west to the Islamic economy in Indonesia in the Industrial Revolution Era 4.0?

\section{LITERATURE REVIEW Western Perception of Islam}

Research launched by Dr. Ayman Talal Yousef in his journal that the Assessment of Islam in Perceptions carried out by the West on Islam there are two important points, namely Fundamentalism and Phobia. With his critical analysis that in highlighting various points of view (thoughts) of Western orientalists who examine more deeply from the negative side that exists in Islam and Arabism. The main idea of Islam itself is Islamic fundamentalism in the context of the concept initiated by Islam, where in Islamic politics, especially after the Iranian Revolution, and the Soviet Union's invasion of Afghanistan in 1979. Thus, if studied more rationally between Islam and the West in The view of Western Orietalism considers that Islam is backward and has not progressed (Yousef, 2013). This is similar to what Sabri Ciftci explained in his journal that Islamophobia and also threats (attitudes) by the anti-Muslim west, this means the perception in the West where Islamophobia is more horrific than just dislike for Muslims, that Islam is terrorist and Islam is hard always do trouble and commotion. Islam in the west itself is a threat to the extent that the west is very anti-Islam (islamophobia) (Ciftci, 2012).

Islam is criticized by infidels with very strong words all over the world. Where this criticism for Muslims must be responsible for arson activities because of hatred and prejudice against Islam. For the west has made a new policy that is applied to Muslims. French policy, for example, began to slap Muslims. So that Muslims are most affected by hate speech, racism, discrimination, fanaticism in various lines, including the workplace environment, educational institutions and also in mosques that are ambushed by fascists. In India itself, Muslims are killed for eating beef, where cows are animals that are considered sacred to Hindus in India. Those (Muslims) who slaughter and consume this beef are whipped and prohibited from going to the mosque to perform worship (Salat). Indian Kashmir has become a detention center as was Germany during Hitler's rule for the Jews (Shukhat, 2021). From the above study, it can be concluded that the Western perception of Islam is a threat in terms of ideology and thought as well as in carrying out a practice that will be carried out by Muslims.

\section{Western Response to Islamic Economy in Era 4.0}

Islam and Religion as seen from Modern Western political, economic and social structures have emerged as a consequence of the rejection of religion which was linked to the Enlightenment and based on secular principles. Asad Zaman, in his research found that many economic systems in the world are contrary to Islamic principles and cannot be adapted to Islamic societies in other parts of the world (Zaman, 2009). So that 
the development of the Islamic economy in the era of the Industrial revolution 4.0, is part of the process of gaining freedom from the clutches of Western colonial institutions. This means that the West's response to the Islamic Economy in Era 4.0 according to researchers, especially in the era of 4.0 (disruption) as it is today is a challenge for the west in competing against the global economy.

Judging from the impact of the journey of Islamic thought and the development of Islam and Christianity, it can be seen when the Crusades took place. Muhammad Yaseen Gada found a scientific idea in his article that Muslims and Christians during the Crusades had a tremendous impact, especially in Western Europe; This war led to the development of European civilization. The Crusades had to include elements of something that could damage and build an economy. The impact of the Crusades can be seen in several socio-religious elements of the Muslim world. Furthermore, the bitter legacy of this war expanded the enmity, hatred and dissent between the West and the Muslim world which is still viewed in one way or another. The impact of this crusade included the emergence of imagery, ideology and symbolism, where the Crusades were so strong and powerful that they had dampened and damaged the positive constructive impact achieved for Western Europe by dealing with the Eastern (Muslim) world. As for the other (positive) impact of the Crusades, namely the interaction between the two (Islam vs Christianity) / West vs East if it is widely highlighted and explored, and if given a wide enough space in public and academic discourse, the possibility of West and East tensions in hostilities can be reduced indefinitely (Gada, 2017). This means that the western world towards Islam from the socio-political side after the Crusades, the economic sphere was more visible in Islamic countries. In addition, from the impact of this crusade diplomatic relations between Europe and Muslims caused Europe to enter on the economic side to the east (Islam) even though there were various obstacles caused by the war (Hillenbrand, 1997: 391-406).

\section{Western Response to Islamic Economy in Indonesia in Era 4.0}

Developments in the field of Political Law that exist in Indonesia within the scope of the Sharia economy itself. Sharia economic law that has been applied in Indonesia is non-formal, in which case sharia economic law in Indonesia is part of the law that lives in society and is enforced juridically. Non-formal terms of sharia economic law in Indonesia can be realized in the form of fiqh mu'amalah, iqtishadiyah or DSN MUI fatwas. While the formal juridical term must be realized in the form of legislation whose formulation is carried out by the authorized party (government official). In turn, the accommodation of the mu'amalah principle gave rise to the politics of sharia economic law. Thus, this is a concrete manifestation that the Indonesian state supports the development of the Islamic economy in Indonesia (Renie et al., 2020). The research launched by Ismaulina found that in implementing the Islamic economic system in this world, especially in Indonesia, it can be a golden momentum (opportunity) aimed at Indonesia's economic recovery as a result of the Indonesian economic recession after the impact of the implementation implemented by the overall Indonesian government policy (national) in order to combat the terrible COVID-19 pandemic (Ismaulina, 2020).

Asep Mulyadi as Deputy Regional Head of BNI Syariah in the Western Region. in a public lecture held by the Faculty of Economics and Business, Islamic Economics Study Program, Padjadjaran University Bandung (2020) that Islamic Banking Innovation in Developing Indonesia in the Industrial Era 4.0 and innovation are two points that need to be underlined related to the current developing potential, namely the 
sharia economy. will be strongly encouraged by the presence of the Industrial Revolution Era 4.0. In this era machines have become a substitute for human power, so we have to mix with what is called the Internet of Things (IoT), and also Artificial Intelligence (AI), besides that we are served with Big Data, and Cloud Computing, as well as Block Chain. The era of the industrial revolution 4.0 is a unique new phenomenon that we are currently experiencing in the majority of countries in the world. The western response to the Islamic economy in Indonesia is expanding until this digitalization era in various real sectors of human life. The thinning of the boundary between the virtual world and the real world affects how the wheel of life runs, a small example in the virtual world or commonly known as e-money. In welcoming this 4.0 industrial revolution era, Islamic economics in general and especially Islamic banks must innovate so that they are always involved (not left behind) in the realm of making the Indonesian economy successful.

\section{METHOD}

This type of research is a normative juridical research. This normative juridical research is a scientific activity carried out based on certain methods, systematics and thoughts aimed at studying something or certain legal phenomena, by analyzing them (Soejono \& Abdurrahman, 1999 : 110). This normative juridical research is also used as library research or document study because this research is conducted or aimed only at written regulations or legal materials (Soekanto \& Mamudji, 2007: 14). The nature of this research is a descriptive legal study. Where this descriptive legal research is intended so that researchers in analyzing are willing to provide an overview or explanation of subjectivity and objectivity that will be discussed in this study as the results of research conducted and this is where researchers do not justify research results (Marzuki, 2005: 191). This study is intended to explore and clarify related to a phenomenon or a social reality that occurs, namely the Western World Response to Islamic Economics, under the pretext of describing a number of variables relating to the problems and units studied between the phenomena that occur, namely the western response to Islamic economics in the era of 4.0 (Disruption) as it is today which has its own challenges for the existence of the Islamic Economy so that it is more developed with superior innovations in meeting the challenges of the national economy in Indonesia.

This study uses qualitative research methods with data sources used are primary and secondary data. Qualitative research was chosen as a data collection method/method for researchers in order to explore and understand the data in order to further explore and be able to answer the western world's response to the Islamic economy in Indonesia, especially in Era 4.0 as it is today. In addition, this method is expected to be able to describe the reality and social complexities that occur in Era 4.0 where the western response to the Islamic economy that exists in Indonesia. The type of research used in this research is library research, where a series of studies in the study of matters related to data collection or research objects, researchers in terms of obtaining primary and secondary data sources are obtained through various types of information from literature/libraries such as journals. -journals and books, internet as well as previous research studies as well as the latest information on various trusted and scientifically justified websites. 


\section{RESULT AND DISCUSSION}

\section{Islamic Economic Philosophy in Era 4.0}

The philosophical opinion by Bertrand Russel (2007) explains that it is nothing more than an attempt to answer the last questions, not only superficially or dogmatically as we do in everyday life or even in the scientific tradition in various knowledges. However, if we look at it critically, in the sense that after everything has been investigated what kinds of problems such questions can cause and after we become aware that from a dogmatic point of view, thinking and confusion in Indonesia, which is the basis for our understanding in everyday life, day. Therefore, philosophizing is of course not just plugging in a question mark specifically by philosophy, including thinking systematically, radically, critically, integrally and reflectively. This will then become the root of the difference between a study of economics and economic philosophy (Athoillah \& Q-Anees, 2013). In economic thought, Imam al-Mawardi is a Muslim scholar, and an interdisciplinary scientist who has contributed to various Islamic economic concepts. al-Mawardi argues that basically the market must run naturally or freely and government intervention on the market is allowed, this serves to monitor various frauds and economic crimes as well as in the context of stabilizing the economy. It is very interesting in this concept that al-Mawardi is in line with the thoughts of John Maynard Keynes, a father of modern economics who initiated the first Keynesian School of Economics. Al-Mawardi's thinking has preceded the modern economic concept of the task of government and market system (Muttaqin \& Nurrohman, 2020).

In contrast to Islamic economic thought by (Nurohman, 2012) he concludes in his research that it is almost always the subject of discussion at the scientific level, especially in the epistemological area. So in terms, the way of economics and Islam is considered to be contradictory to each other. The contradiction between these terms raises the question of whether Islamic economics is a science or a doctrine. Baqir alShadr and Anas Zarqa in their analysis explained that all economic systems, be they capitalist, socialist or Islamic, have been born from the doctrines that teach economics. These doctrines gave birth to a discipline of economics. Therefore, the term Islamic economics is parallel to capitalist and socialist economics in many ways in general meaning, especially regarding the methods or ways in which people use and solve various economic problems themselves. In the methodological area, Zarqa' explains that the Qur'an and al-Sunnah have been considered as sources of scientific term normativism which contain positive descriptive assumptions. These two statements have also entered into conventional economics. As a result, Zarqa' stated that science is not measured by its descriptive assumptions which are rooted in empirical reality only, but also rooted in the normative assumptions that form the framework of the science. A science, be it capitalist, socialist or Islamic economics, is a doctrine that is thick with the presence of normative assumptions. From this doctrine, what was then formulated by theory and science was built, after experiencing the processes and practices that have occurred among the community.

\section{Maqaid Syariah as the Basic Foundation of Islamic Economy in the Industrial Revolution 4.0 Era}

In recent years, many Islamic countries have proposed an Islamic economic system that reaffirms that traditional Islamic values are being revived. These countries want a complete system that includes specific patterns and areas of social and economic 
behavior for believers that does not involve reformulation of Islamic ideology or compromise of its teachings. In this economic practice, it is made to comply with the commands contained in the Qur'an, without reinterpreting the basic doctrine. The process of Islamization of the economic system involves economic institutions with a certain Islamic identity. The process seems to be gaining momentum over time. New institutions have been established, such as Islamic banks and development aid agencies, with the aim of translating sharia economic ideals into practical business solutions. Islamic economics is closely related to and is part of the concept of Islamic life.

Both the Qur'an and the Sunnah have a lot to say about economic issues. In the welfare of mankind while on this earth and their welfare in the hereafter are interrelated. Islamic teachings in the economic field, for example, which in this case mu'amalah is related to a series of welfare problems which are broadly interpreted, this includes several terms including justice, compassion, welfare, wisdom, and emphasizes brotherhood and equality and these economic problems become very basic and have deep-rooted significance for people all over the face of the earth. In short, this Islamic moral teaching establishes ethical guidelines to control the effectiveness of all economic behavior. Economic institutions, for example, must facilitate the achievement of Islamic goals and objectives. These economic activities and endeavors are assessed and measured in moral terms and must be carried out in accordance with the work ethic and system norms based on Islamic values. Fundamentals of Islamic Economics (Ghofur, 2017) argues that in order to achieve the goals of Islamic economics, including:

1. Aims to achieve the welfare of the community both in this world and in the hereafter, optimally achieving all needs in accordance with shariah, both individually and in society. Achievement of resource needs optimally without waste and can preserve all the sustenance that has been provided by Allah swt.

2. Individual relative property rights are recognized as business and work in a lawful manner and are used for things that are right, good and lawful as well.

3. It is forbidden to hoard property, merchandise and so on that can cause distress for others who need it more, and hinder the pace of the economy.

4. In the wealth of the rich there is a right for the poor, therefore Islamic economics must distribute half of its wealth to zakat or alms, according to the verses of the Qur'an Surah Al-Hadid verse 7 which means as follows: Believe in Allah and His Messenger and spend part of your wealth which Allah has made you master. So those who believe among you and spend (part) of their wealth will have a great reward.

5. The prohibition of usury or additional in all aspects of the economy, both banking and buying and selling (muamalah).

In contrast to research by (Ahyani \& Muharir, 2020) that the Riba Norm that exists in Islamic Economics in this case Maqa'id Syariah as the Basic Foundation of Islamic Economics is a matter of khilafiyah and the need for development of thought, as well as the law of Bank Interest in principle is mutual tolerance and respect and mutual respect between various opinions must be put forward. Capitalist economy if combined with sharia economy where in the Industrial Revolution 4.0 era now it has been combined into a dual banking system so that both of them inevitably have to be carried out together so that they are mutually beneficial (win win solution) to make Maqașid Syariah with the principle of mercy for all nature (Ahyani et al., 2020). 


\section{The Development of the Islamic Economy in Responding to the Challenges of Era}

4.0

The development of the Islamic economy in the world can be seen from the emergence of Islamic banks in various countries. The Islamic economy began with the presence of Islamic banking as a financial institution based on ethics, based on the Qur'an and al-Hadith. The main milestone of the establishment of Islamic banking is the operation of Mit Ghamr Local Saving Bank 1963 in Cairo, Egypt. In some of them in countries in the 1970s, a number of Islamic-based banks then emerged. According to Yeni Cahyono and Edy Kurniawan in (Musyafah, 2019 : 421) In the Middle East, including the Dubai Islamic Bank (1975), Faisal Islamic Bank of Sudan (1977), Faisal Islamic Bank of Egypt (1977) and Bahrain Islamic Bank (1979). As for the AsiaPacific, the Philippines Amanah Bank was founded in 1973 by presidential decree, and in Malaysia in 1983 the Muslim Pilgrims Savings Corporation was founded which aims to help those who want to save for the pilgrimage.

The above invites a strong reaction from the West that is excessive to the superiority of the capitalist economic system, after the collapse of the socialist economic system in the 1980s this also encourages the expected strengthening of the tendency to place the Islamic economic system as an alternative outside the capitalist economy. This resulted in the establishment of Islamic economic institutions, since the establishment of the Islamic Development Bank in 1975 in Jeddah. This is not only happening in the Middle East region, but also outside the region. When the economic crisis hit the world a few years ago, Islamic banking became a savior. This system is becoming a major growth area for international financing. So that this has become a trigger for many countries in the world, competing to become the global center of the Islamic finance business. As in London, which is far ahead of New York, this is a major milestone in the Islamic economy in the European region.

\section{Response from the West towards the Islamic Economy in the Industrial Revolution 4.0}

Islam is an Abrahamic religion which in its journey later transformed into a great civilization. Even Islam itself, in the period before the 13th century AD or precisely before the renaissance in the Western World, Islamic civilization has become the leader and center of world civilizations. However, whether it is recognized or not that the West has been indebted to Islam for the progress of its civilization as it is today, not a few and not infrequently Westerners admit it Thus, the Western response to Islam as a source of civilization is not absolutely correct but is divided into positive responses and some respond negatively (Wasito, 2013). With various responses from the western world, there is also a strategic role in the state as found by (Ahyani \& Hasanah, 2020) regarding the growth of Islamic economic practices, especially in Indonesia, it can be said to be very fast after getting some support by the government in the form of a political economy that based on Islamic economic principles that can be realized in various economic fields that apply an Islamic economic system, such as Sharia banking, Sharia insurance, sukuk, Sharia capital markets, public finance, and so on. The government needs to be continuously and significantly encouraged to implement an economic policy that is oriented towards an Islamic economic system, such as zakat which was originally only a form of taxable income reduction or PPKP being increased to a tax deductible or tax deductible, converting state-owned banks into Islamic banks for marketing to banks. Sharia continues to experience a significant increase, meaning 
that it is experiencing rapid progress, thus it is hoped that its application to the political aspects of Islamic economics is even more widespread in order to contribute to accelerating the realization of a just and prosperous economic order.

The presence of the Islamic Economic system in the current global economy in the era of the industrial revolution 4.0, has the potential to generate different responses according to the interests of each party or country and the institutions it adheres to. For example, for countries or financial institutions that adhere to a capitalist or liberal system, it is very possible to consider that the presence of an Islamic economic system is a threat that continues to experience the sustainability of the capitalist system, this is because this system is feared to interfere with market share and erode their profits (the West) in the global economy.

\section{The West's Contribution to the Islamic Economy in Indonesia in responding to the challenges of the Industrial Revolution 4.0}

Conventional economic studies not only have weaknesses, but also have advantages. Its main weakness lies in its secular paradigm that separates positive and normative economics, in the absence of a strong relationship between micro and macroeconomics, thus neglecting moral and ethical values in their descriptive and predictive functions. One of the advantages is that it simplifies conventional economic theories with mathematical and calculus models. In the era of globalization and trend phenomena in the development of economics, there have been many opportunities and challenges, including efforts to develop Islamic economics. Thus the development of Islamic economics in the future is required to continue to learn from experience, both experience in terms of success and failure of conventional economics, besides that it is also necessary to take advantage of various creative and innovative new approaches to realize an Islamic economy that is rahmatan lil'alamin (Kholis, 2008).

Islamic economics is also one of the approaches to the economic system in the formation of a pluralistic community economy. Many countries in the world are taking a conventional economic approach in fulfilling their self-interest, this approach is generally more developed in the western world. This success is in fact they have failed in realizing the actualization of the social vision and normative goals of economics itself (Chapra, 2001, p. 45).

Over the last two decades, Islamic finance has continued to develop, besides that Islamic finance has experienced quite rapid growth throughout the world. Until now, the Islamic financial system has been running in more than 50 countries, both Muslim and non-Muslim majority countries. Regarding the principle of profit sharing and risk in Islamic finance, the most suitable for real sector financing are SMEs in welcoming inclusive and quality economic growth. Meanwhile, the principles of profit and risk sharing as well as asset-based financing will encourage better risk management so as to avoid credit booms. Apart from the sharia commercial finance sector, there is also a sharia social finance sector such as zakat, infaq, and waqf or ZISWAF for short which has a lot of great potential in the realm of realizing the distribution of income and wealth as well as overcoming inequality among the people. ZISWAF has a very important role in providing the Social Safety Net or JPS and also ensuring the fulfillment of basic needs for the poor, then reducing inequality, and encouraging the wheels of the economy to spin, and utilizing idle funds or unproductive funds to be used productively. As for waqf, it is able to deliver to the realm of national development through community economic empowerment and increased investment in the realm of 
welfare both in the religious and education sectors as well as social services (Nurrohman \& Prawito, 2020).

The global economy in 2020 is projected to grow faster, reaching 3.4\%. However, major countries will still grow at a slower pace. Energy commodity prices are projected to weaken again in 2020. The decline in crude oil prices, for example, is predicted to come from a faster increase in supply in line with the operation of a new pipeline from the United States. Non-energy commodities are projected to experience a more stable movement, especially in terms of main commodities in Indonesia. Palm oil prices are also predicted to be stable while nickel is expected to increase, this is driven by the government's policy that prohibits the export of crude nickel from January 2020. Meanwhile, the price of precious metals if calculated as a whole is projected to also increase. Therefore, Indonesia's economic growth in 2020 is not expected to reach the target set in line with the magnitude of the downside risk or the risk of loss faced. In terms of investment and household consumption are also expected to be the main drivers for growth. Related to this investment performance is expected to increase with the passing of the Omnibus Law or the Law on Job Creation. Household consumption is also driven by low inflation rates, such as the issuance of pre-employment cards, and an increase in the allocation of the National Health Insurance Jamkesnas. While other matters related to exports are expected to increase, this is in line with the increase in exports of Crude Palm Oil or CPO (palm oil) to India and along with the passage of several Free Trade Agreements or free trade throughout 2020 to 2021 (Bappenas, Edition Vol 3 No. February 4, 2020).

However, Indonesia's economic growth is estimated to be better in the third and fourth quarters of 202, this is in line with the relaxation of the PSBB. If we look at the expenditure side, this economic recovery depends on the acceleration of government spending and the recovery of the global economy. Then from the side of the business field, and the processing industry and trade, these are the sectors that have the most influence on economic recovery in Indonesia. The information and communication service sector, for example, as well as health services, is expected to continue to grow during the pandemic (Bappenas, 2020).

The capitalist economic system is a system of economic organization that has a special characteristic, namely where rights are private property over the means of production and distribution and their use in order to achieve profits in very competitive conditions. This capitalist economic system is the result of the thought of Adam Smith, a classical school figure in which world economists consider that this classical school of thought is the basis of the capitalist economic system. The doctrine taught is The Welth of Nation which explains the pillars of capitalism. From that emerged the theory of the capitalist economic system, discussing the value of goods and services, then the price structure, namely prices in the production area, then prices in determining consumption and prices in determining production methods, the rationale of Adam Smith's theory was able to survive until the economic depression occurred. in 1929, at that time John Maynard Keynes (1883-1946) was a British economist who had changed the theory and practice of macroeconomics and world economic policy. Keynes appeared and succeeded in expressing his theory that a new and better economic system can be built, this concept or theory of Keynesian thought requires government intervention in determining economic policy, as a result this is the beginning of the fall of the capitalist economic system, but over time for more or less From 30 years there has been a world oil crisis in 1973, so the capitalist economic system is back with a new name called 
neoliberalism (Agustiati, 2009). So that in this case the Islamic economy which is the development of Islamic thought must also be accompanied by government intervention in this case in the realm of determining economic policy in Indonesia.

Characteristics of a liberal economy include the smaller role of the government in the economy, including in terms of ownership of production assets. With the sale of SOEs to private parties, both national and foreign private, this makes the Indonesian economy more liberal. Then related to the role of the Indonesian government in the WTO or the World Trade Organization and the GATT agreement or the General Agreement on Tariffs and Trade. Thus, Indonesia in the Indonesian world trade system is included in global capitalism (Yan, 2016). In his research findings, Raflyah Hasan Yan revealed that the implementation of the capitalist economic system in Indonesia is still ongoing, this is because there are several factors that are still implemented by the Indonesian government, including first, the abolition of subsidies from the government. This means that the prices of strategic goods, which have been determined by the government, are then gradually handed over to the free market share. Second, the value of the rupiah exchange rate that is floated freely or floating rate. Thus, the value of the rupiah exchange rate must be returned to the market mechanism as well. Third, the privatization of SOEs, in this case the sale of shares to the public and resulted in a reduction in the percentage of ownership of the Government of the Republic of Indonesia. Fourth, the participation of the Indonesian government in the WTO and the GATT agreement, so that Indonesia enters the liberalization of the world economy which makes Indonesia enter into global capitalism.

Islamic economics with a socio-economic dimension or muamalah requires further understanding and research, this is because the muamalah aspect is more dynamic and flexible in the development and application of its law than the teachings of Islam itself which have dimensions on Tho'in worship and Prastiwi in (Sumarsono, 2016). Therefore, all economic activities in Indonesia in particular must always be based on existing sources of Islamic law, but also be able to compete in the realm of renewal in carrying out economic activities, this is intended so that Muslims in Indonesia are not left behind in terms of the economy at the national and international levels international. Meanwhile, the capitalist economic system provides opportunities for each individual individual with the freedom to own property, and this system also dominates the economic system used by countries in this world. Then related to the Islamic economic system until now it is an alternative concept for the economic system in Indonesia that is prosperous with the existing economic system in Indonesia, namely the capitalist economic system. sources of Islamic law, especially the Koran and alHadith.

The location of the difference between the Islamic economic system and the capitalist economic system, for example, is not only in things that are applicable but must be seen in the philosophy. These different philosophies are built with different goals and norms and principles. This is because it is related to one's beliefs in influencing the perspective of shaping one's personality, one's behavior, one's lifestyle, and one's tastes. In a broader context, beliefs can also influence attitudes towards the behavior of other people, resources, and the environment. In the capitalist system, God is retired or retired God. This is reflected or can also be implemented into the concepts of laissez faire (Government intervention) and the invisible hand. (Budiman, 2014) in his research it was found that from this philosophy we can see that the purpose of the capitalist economy is only a concept of economic growth for the sake of achieving 
individualist satisfaction of certain circles. However, the philosophy of Islamic economics in the letter al-Muthaffifin verses 1 - 6. Allah SWT says which means: A big accident for people who are cunning/cheat. Those are people who when they receive their dose from someone else they ask for it to be added. And when they measure and weigh for others, they reduce it. They do not think that they will be resurrected in the hereafter. 5) One day in the great time (hereafter). That is the day when humans stand before His Lord, the ruler of the universe.

The implication of the western response to the existence of a sharia economy in Indonesia is a golden opportunity for Indonesia to develop a sharia economy, one of which is the halal industry, halal tourism (religion), sharia economic brand, cash waqf (Ahyani 2021), the potential of the halal industry sector in Indonesia can be developed through halal food (halal food) (Ahyani, Mahfud, Rohmat, et al. 2021), halal fashion, halal cosmetics, and so on, this means that economic freedom in Indonesia needs to be developed (Ahyani, Slamet, and Tobroni 2021). The view (Ahyani, Muharir, and Ulya 2021) that halal tourism can also be developed in Indonesia, with various potentials that exist in Indonesia. Another implication related to the western response to the sharia economy in Indonesia is the presence of a diversity of halal food (Ahyani, Mahfud, Waluyo, et al. 2021). However, the development of this potential needs to make the resulting production must be based on the principles of benefit and justice (Susilawati, Yarmunida, and Elwardah 2021). The benefit that is put forward by Islamic economics is a real need where justice is very meaningful in the economy, especially in Indonesia (Muflihin, 2018).

However, in the development of Islamic economics there has been a mixing or dualism system, from two different systems (Capitalist-Sharia). Sharia economics, which is clearly different from the capitalist economic system, is combined to obtain as much profit or profit as possible, which is profit oriented, in contrast to social oriented which aims for the social life of the community and or aims to increase good deeds. In line with the above, (Anwar, 2019) in his journal emphasizes that the description of the response of Muslims to the emergence of the industrial revolution 4.0 era or this era of disruption, where the situation of the industrial world movement is no longer parallel means it is not linear. So that the changes run quickly, are fundamental in nature and destroy the old order patterns and bring up new order patterns. So Islam must be able to match more innovative and disruptive strategies. Both from the business world, transportation to education patterns. This means that in the Industrial Revolution 4.0 era, the western (Christian) contribution to the economy in Indonesia actually creates new opportunities for (eastern) Islam towards a better one. So that Indonesia remains in principle, namely prioritizing and developing the potentials that exist in the sharia economy in Indonesia, where this sharia economy is a huge golden opportunity in the direction of a prosperous and prosperous Indonesia.

\section{CONCLUSION}

Regarding the discussion above where in the research problem that examines how the response and contribution of the west to the Islamic economy in Indonesia in the Industrial Revolution Era 4.0, it can be concluded including: First, the system in Western culture that has been applied to the Islamic world, namely capitalism as domestic economic development, then the Islamic world is more inclined to the system which is directed to the first form. The capitalist countries were the first to infiltrate the 
Islamic world and build their existing bases in the Islamic world. The Islamic world views that in a free enterprise system, countries that are not developed are forced to compete with developed countries. Therefore underdeveloped countries must be able to organize in order to try to mobilize all resources by following guided economic policies, so that in this case related to the western world's response to the Islamic economy in Indonesia the Industrial Revolution Era 4.0 is that the Western economic system is intended to embrace the Islamic economic system and support the existence of this Islamic economic system, as a result the western world implements a free business system based on capitalism that prioritizes capital for economic development in the Islamic world.

Second, the Keynesian theory or Keynesian economy regarding total expenditure in the economy and its influence on output and inflation in Indonesia The Industrial Revolution Era 4.0 is classified as a new and better economic system that can be built, this Keynesian concept or theory of thought requires government intervention in determining economic policy, so that in this case the Islamic economy which is the development of Islamic thought must also be accompanied by government intervention in this case in the realm of determining economic policy in Indonesia. Contribution from the west to the economy in Indonesia is a necessity which in fact the State of Indonesia is not an Islamic State. However, in its scope, Islamic law in Indonesia in this case the sharia economy is subject to the national economic system, although sharia economics and conventional economics in Indonesia have their own legal umbrella.

The implication of the western response to the existence of a sharia economy in Indonesia is a golden opportunity for Indonesia to develop a sharia economy, one of which is the halal industry, halal tourism (religion), sharia economic brand, money waqf, the potential of the halal industry sector in Indonesia can be developed through halal food ( halal food), halal fashion, halal cosmetics, and so on, this means that economic freedom in Indonesia needs to be developed. In addition, halal tourism can also be developed in Indonesia, with various potentials that exist in Indonesia. Another implication related to the western response to the Islamic economy in Indonesia is the presence of a diversity of halal food. However, the development of this potential needs to make the resulting production must be based on the principles of benefit and justice, where this benefit is carried out by prioritizing sharia economics as a real need where justice is very meaningful in the economy, especially in Indonesia.

\section{REFERENCES}

Ahyani, H, dan Nurhasanah, E. 2020. "Peran Strategi Politik Islam Terhadap Perekonomian Di Indonesia." Mutawasith: Jurnal Hukum Islam 3 (1) : 18-43. https://doi.org/10.47971/mjhi.v3i1.185.

Ahyani, Hisam, dan Muharir. 2020. "Dialog Pemikiran Tentang Norma Riba, Bunga Bank, Dan Bagi Hasil Di Era Revolusi Industri 4.0." Eksisbank (Ekonomi Syariah dan Bisnis Perbankan) 4 (2): 232-54. https://doi.org/10.37726/ee.v4i2.140. 2021. "Perspektif Hukum Ekonomi Syariah Tentang Wakaf Uang Di Era Revolusi Industri 4.0." lan Tabur: Jurnal Ekonomi Syariah 2 No.2: 85-100. https://doi.org/10.1234/lan\%20tabur.v2i2.4184.

Ahyani, Hisam, Dian Permana, dan Agus Yosep Abduloh. 2020. "Dialog Pemikiran Tentang Norma Riba, Bunga Bank, Dan Bagi Hasil di Kalangan Ulama." 
Kordinat: Jurnal Komunikasi antar Perguruan Tinggi Agama Islam 19 (2): 247264-264. https://doi.org/10.15408/kordinat.v19i2.18899.

Agustiati. 2014. "Sistem Ekonomi Kapitalisme." Academica 1 (2). http://jurnal.untad.ac.id/jurnal/index.php/academica/article/view/2326.

Ahyani, Hisam, Dian Permana, dan Agus Yosep Abduloh. 2020. "Dialog Pemikiran Tentang Norma Riba, Bunga Bank, Dan Bagi Hasil di Kalangan Ulama." Kordinat: Jurnal Komunikasi antar Perguruan Tinggi Agama Islam 19 (2): 247264-264. https://doi.org/10.15408/kordinat.v19i2.18899.

Athoillah, M. A., \& Q-Anees, B. (2013, Februari 13). Filsafat Ekonomi Islam. Retrieved Nopember 11, 2020, from https://uinsgd.ac.id/filsafat-ekonomi-islam/

Ansori, Aan. 2016. "digitalisasi ekonomi syariah." Islamiconomic: Jurnal Ekonomi Islam 7 (1). https://doi.org/10.32678/ijei.v7i1.33.

Anwar, Saeful Anwar. 2019. "Revolusi Industri 4.0 Islam Dalam Merespon Tantangan Teknologi Digitalisasi." AT-Tuhfah: Jurnal Studi Keislaman 8 (2): 16-28. https://doi.org/10.36840/jurnalstudikeislaman.v8i2.203.

Ahyani, Hisam. 2021. "Sharia's Economic Law Perspective About Cash Waqf in The Era of The Industrial Revolution Four Points Zero." Al-Mawarid Jurnal Syari'ah \& Hukum 3 (1): 21-34.

Ahyani, Hisam, Muntaha Mahfud, Waluyo Rohmat, Ulya Widadatul, dan Muharir. 2021. "The Potential Of Halal Food On The Economy Of The Community In The Era Of Industrial Revolution 4.0." Indonesia Journal of Halal 3 (2): 11228. https://doi.org/10.14710/halal.v3i2.10244.

Ahyani, Hisam, Muntaha Mahfud, Rohmat Waluyo, Widadatul Ulya, dan Muharir Muharir. 2021. "The Potential of Halal Food as A Driver of the Economic Development in Regional Community." Jurnal Pariwisata Terapan 4 (2): 16382. https://doi.org/10.22146/jpt.63771.

Ahyani, Hisam, Muharir, dan Widadatul Ulya. 2021. "Potensi Wisata Halal Kota Banjar, Jawa Barat di Era Revolusi Industri 4.0." Tornare: Journal of Sustainable and Research 3 (1): 4-12. https://doi.org/10.24198/tornare.v3i1.31511.

Ahyani, Hisam, Memet Slamet, dan Tobroni. 2021. "Building the Values of Rahmatan Lil 'Alamin for Indonesian Economic Development at 4.0 Era from the Perspective of Philosophy and Islamic Economic Law." Al-Ihkam: Jurnal Hukum \& Pranata Sosial 16 (1): 121-51. https://doi.org/10.19105/allhkam.v16i1.4550.

Susilawati, Nilda, Miti Yarmunida, dan Khairiah Elwardah. 2021. "The Halal Fashion Trends for Hijabi Community: Ideology and Consumption." Dinar: Jurnal Ekonomi Dan Keuangan Islam $8 \quad$ (2): 35-46. https://doi.org/10.21107/dinar.v8i2.9683.

Muflihin, M. D. (2018). Konstruksi indikator halal dalam perkembangan industri halal fashion (Doctoral dissertation, UIN Sunan Ampel Surabaya).

Ciftci, Sabri. 2012. "Islamophobia and Threat Perceptions: Explaining Anti-Muslim Sentiment in the West." Journal of Muslim Minority Affairs 32 (3): 293-309. https://doi.org/10.1080/13602004.2012.727291.

Chapra, M. U. (2001). The Future of Economics; an Islamic Perspective. Jakarta: SEBI.

Dharmalaksana, Wahyudin, dan Lutfiyah Arifin. 2019. "Kontribusi UIN SGD Bandung Dalam Mengembangkan Ekonomi Syariah Di Era Revolusi Industri 4.0." 
Adliya: Jurnal Hukum dan Kemanusiaan 13 (1): 39-56. https://doi.org/10.15575/adliya.v13i1.4459.

Darmalaksana, Wahyudin. 2015. "Filsafat dan Politik Hukum Islam tentang Perbankan Syariah: Kajian Filsafat dan Politik Hukum Islam bagi Perkembangan Perbankan Syariah di Indonesia." Doctoral, UIN Sunan Gunung Djati Bandung. http://digilib.uinsgd.ac.id/5230/

Gada, Muhammad Yaseen. 2017. "Rethinking The Impact Of The Crusades On The Muslim-Christian Thought And Development." QIJIS (Qudus International Journal of Islamic Studies) 5 (2). https://doi.org/10.21043/qijis.v5i2.2259.

Ghofur, A. (2017). Pengantar Ekonomi Syariah: Konsep Dasar, Paradigma, Pengembangan Ekonomi Syariah. Depok: Rajawali Pers. Hillenbrand, Carole. 1997. The Crusades: Islamic Perspective. Edinburgh: Edinburgh University Press.

Ismaulina, Ismaulina. 2020. "Sharia Economy Momentum to Restore Economic Recession Due to Pandemic Disruption in Indonesia." International Journal of Business, Economics \& Management 3 (1): 196-202. https://doi.org/10.31295/ijbem.v3n1.189.

Karim, Adiwarman. 2020. "Ekonom: 2021 Bawa Angin Segar untuk Ekonomi Syariah." Republika Online. 2 Desember 2020. https://republika.co.id/share/qkpnmy383.

Kholis, Nur. 2008. "Masa Depan Ekonomi Islam dalam Arus Trend Ekonomi Era Global.” UNISIA 31 (68). https://doi.org/10.20885/unisia.vol31.iss68.art5.

Muttaqin, Rizal, dan Nurrohman Nurrohman. 2020. "Islam Dan Pasar: Studi Atas Pemikiran Abū Hasan Al-Māwardī Tentang Mekanisme Pasar." Maro: Jurnal Ekonomi Syariah Dan Bisnis 3 (1): 1-11. https://doi.org/10.31949/mr.v3i1.1921.

Mannan, M. A. (1993). Teori dan Praktek Ekonomi Islam. Yogyakarta: PT Dana Bhakti Wakaf. Marzuki, P. M. (2005). Penelitian Hukum. Jakarta: Prenadamedia Group.

Musyafah, Aisyah Ayu. 2019. "Perkembangan Perekonomian Islam di Beberapa Negara di Dunia." Diponegoro Private Law Review 4 (1). https://ejournal2.undip.ac.id/index.php/dplr/article/view/5103

Nurrohman, D. (2013). Hakikat Dan Konstruksi Keilmuwan Ekonomi Islam. Epistemé: Jurnal Pengembangan Ilmu Keislaman, 7(2), 245-266. https://doi.org/10.21274/epis.2012.7.2.245-266.

Renie, Elsy, Thohir Luth, Sihabbudin, dan Siti Hamidah. 2020. "The Development of the Politics of Law in Indonesia's Sharia Economic Environment." IOP Conference Series: Earth and Environmental Science 469 (April): 012058. https://doi.org/10.1088/1755-1315/469/1/012058.

Russell, B. (2007). Sejarah Filsafat Barat. Yogyakarta: Pustaka Pelajar. Ridwan, Muhammad. 2010. "bank syariah di indonesia kajian perspektif filsafat hukum islam.” Qistie 4 (1). https://doi.org/10.31942/jqi.v4i1.596

Soejono, \& Abdurrahman. (1999). Metode Penelitian Suatu Pemikiran dan Penerapan. Jakarta: Rineka Cipta.

Soekanto, S., \& Mamudji, S. (2007). Penelitian Hukum Normatif. Jakarta: PT Raja Grafindo Persada.

Sumarsono, Dicky. 2016. "Sistem Perekonomian Negara-Negara Di Dunia." Jurnal Akuntansi dan Pajak 16 (02). https://doi.org/10.29040/jap.v16i02.146.

Syarif, Nurrohman, dan Ponsen Sindu Prawito. 2020. "Pertumbuhan Ekonomi Islam Di Indonesia: Studi Kasus Perkembangan Keuangan Komersial Syariáh Dan 
Keuangan Sosial Syariáh.” Economica, Jurnal Ekonomi Islam. http://journal.walisongo.ac.id/index.php/economica/index

Shukhat, Ayesha. 2021. "Islamophobia and Western World." Modern Diplomacy (blog). 13 Februari 2021. https://moderndiplomacy.eu/2021/02/13/islamophobiaand-western-world/.

Wasito. 2013. "Respon Barat Terhadap Islam Sebagai Sumber Peradaban." Tribakti: Jurnal Pemikiran Keislaman 24 (2). https://doi.org/10.33367/tribakti.v24i2.174.

Yousef, prof Ayman Talal. 2013. "Stereotyping Islam in Western Perceptions between Fundamentalism and Phobia: Analytical and Critical Reading." Arab American University. 1 Juni 2013.

https://www.aaup.edu/publication/ayman.yousef/article/stereotyping-islamwestern-perceptions-between-fundamentalism-and-phobia-analytical-andcritical-reading.

Yan, Radlyah Hasan. 2016. "Eksistensi Sistem Ekonomi Kapitalis Di Indonesia." Jurnal Ilmiah Al-Syir'ah 8 (1). https://doi.org/10.30984/as.v8i1.45.

Zaman, Asad. 2009. "Islamic Economics: A Survey of the Literature: I." Islamic Studies 48 (3): 395-424.

Bappenas. (2020). Perkembangan Ekonomi Indonesia dan Dunia (Triwulanan) Edisi Vol.4, No.2 Agustus 2020. Jakarta: Kedeputian Bidang Ekonomi Kementerian PPN / Bappenas.

Bappenas, K. P. (Edisi Vol 3 No 4 Februari 2020). Perkembangan Ekonomi Indonesia dan Dunia Triwulan IV 2019. Jakarta. 